\title{
Augustus Scriptus: Referencing the 'real' in Propertius
}

Author:
Johan Steenkamp ${ }^{1}$ (
Affiliation:
'Department of Ancient
Language and Text Studies,
Faculty of Theology,
North-West University,
Potchefstroom, South Africa
Corresponding author:
Johan Steenkamp,
johan.steenkamp@nwu.ac.za
Dates:
Received: 17 June 2019
Accepted: 26 Aug. 2019
Published: 21 Nov. 2019
mobile device
to read online.
How to cite this article:
Steenkamp, J., 2019,
'Augustus Scriptus:
Referencing the 'real' in
Propertius', In die Skriflig
53(2), a2510. https://doi.org/
10.4102/ids.v53i2.2510
Copyright:
C) 2019. The Authors.
Licensee: AOSIS. This work
is licensed under the
Creative Commons
Attribution License.

The main aim of this article is to understand how Augustus is written into life in the storyworld of Propertius. It traces the development of the character in the story-world over time with due regard to the parallel historical narratives that were told about the historical Augustus. The investigation proceeds from a content analysis of the incidence of references (overt and oblique) to Augustus Caesar in the extant text of Propertius. This approach assumes that quantitative data, that is, frequency of incidence, spatial or temporal dimensions of incidence and the location of a reference in the broader context, are important indicators of meaning. The investigation presents its content analysis and the interpretation of this analysis. The investigation also relies to a certain extent on narratological analytical concepts, because Augustus is written into life by the Propertian text as a character which exists, to a certain extent at least, in a narrative. The investigation concludes that Augustus is not a fully developed character in the Propertian texts. Nevertheless, Augustus is revealed to be a distant ruler mostly associated with military authority and wealth; at some instances, he is regarded as a messianic figure, which is also present in other poets. Most notably, the content analysis reveals a consistent engagement between the speaker in the Propertian poems and the power wielded by Augustus.

Keywords: Augustus; Propertius; content analysis; Latin poetry; elegy.

\section{Introduction}

The main aim of this article is to understand how Augustus is written into life in Propertius. As the Propertian poems are essentially fictional, Augustus exists in the texts as a character in a storyworld or worlds and is a created entity - much like the elegiac puella Cynthia. Yet, Augustus, unlike Cynthia, also exists independently of the Propertian poems in the so-called real-world or, if we want to be more exact, he exists as a written entity in other texts. The main problem the article addresses is to what extent the biography of the written Augustus in Propertius can inform that of the real Augustus and how far the real Augustus limits the biography of the Propertian written Augustus.

This article thus has both a literary and a historical aim. On the one hand, it explores how the literary texts create those characters that also have a life outside the texts and, on the other, it tries to mine the literary productions for historical purposes. For the period between the late-thirties and early-twenties BCE in Rome - more or less the time in which Propertius was active, the comparative lack of eyewitness accounts, so to speak, is particularly vexing. Momentous changes were taking place on political, social and cultural level - changes that, we know now, would have far-reaching ramifications. The magnitude of the problem was memorably deplored by Sir Ronald Syme (1950[1939]:4), one of its greatest historians:

The written history of the time has vanished utterly, no political speech survives, no pamphlet, no memoirs. Compared with what went before and what came after, the Age of Augustus acquires the paradoxical dignity of an obscure and highly controversial period. Recourse must be had to social documents - with due caution; to the Augustan poets - again with due caution. And silence itself will be revealing. Important truths are often awkward truths, to be covered and disguised, from fear, from complicity, or for comfort.

The literary aims of the article are more ambitious. As it has been convincingly argued (Levene \& Nelis 2002:ix-Xv et passim.) that Augustan poets did not, in fact, base their handling of historical topics on historiographic conventions, it follows that even their historical material must be interpreted according to the literary conventions of the genre in question.

Before commencing, some important remarks must be made. The investigation assumes that Caesar Augustus in Propertius is a written entity created in a story-world and constructed by the text according to literary conventions over a period of time (approximately 30 to $16 \mathrm{BCE}$ ). It is also 
assumed that the Propertian text is, to some extent, a narrative or, at least, contains narratives. The story-world created by the Propertian text is not completely removed from the historical world in which it was created; in fact, it can be said that the Propertian story-world depends upon its historical context for its art. As the Propertian texts contain descriptions of historic persons, it is also historiographic in so far as it contains a character based upon a historic character. Thus, the poetry of Propertius can be read as historiography of a narrative kind. The relation between the written Augustus and the historic one is unclear but intelligible.

The analysis of Caesar Augustus in Propertius will proceed from a content analysis. Firstly, however, the aims, advantages and disadvantages of this approach will be delineated. Thereafter, because the character of Augustus will be analysed as a character in a story-world, pertinent narratological terms and methods will be discussed as far as they apply to the following analysis. Lastly, the final analysis will proceed from the analysis with due regard for problematic passages revealed by the content analysis.

\section{Content analysis}

In order to analyse the character of Caesar Augustus in the Propertian corpus, a content analysis of the incidence of mentions of the character will be presented. This approach assumes that quantitative data, that is, frequency of incidence, spatial or temporal dimensions of incidence and the location of a reference in the broader context are important indicators of meaning. This approach also has several weak points as will be discussed, but it has the one advantage that the data presented here will be transparent and replicable.

In practice, a content analysis starts with a 'word search' (in this case mentions of Caesar Augustus). Words, phrases or concepts are identified in a text or corpus, incidence and frequency are assigned, a quantitative weighted value, and associated terms and concepts are plotted out. Yet, this is usually not sufficient. This word search often has to be expanded to include latent meanings, which entails judging implied meaning and meaning dependent on context. The analysis of the results of the content analysis in the present study will attempt to take such cases into account without obscuring the larger picture presented by the content analysis.

Content analysis is mainly used on so-called big data in mass media 'to identify and document the attitudes, views, and interests of individuals, small groups, or large and diverse cultural groups' (Drisko \& Maschi 2016:2). Content analysis has, since its initial use in the 1950s, accrued a large body of theory which has crystallised into a general convention with the advent of the high powered computer in the 21st century. Today, content analysis is divided into: (1) basic content analysis, (2) interpretive content analysis and (3) qualitative content analysis (Drisko \& Maschi 2016:3-5). These are often used as alternative approaches, but seem to be successive improvements on a methodology that started during the first half of the 20th century. Berelson (1952:18), one of the first to look at content analysis from a theoretical position, defined what was then 'content analysis' and is now regarded as 'basic content analysis' as follows: 'a research technique for the objective, systematic and quantitative description of manifest content of communication'. Interpretive content analysis moved away from analysing only manifest content and turned to analysing latent content as well. Under latent content is understood connotative meanings, implicit meaning over several sentences or paragraphs, and context. ${ }^{1}$ Qualitative content analysis in the 21st century has moved even further away from the manifest content as object of inquiry, and emphasises the value of qualitative analytical tools (Mayring 2000). These qualitative analytic tools, not entirely surprising, turn out to be more or less familiar to the literary critic. Drisko and Maschi (2016:82-83) name specifically discourse analysis, critical theory (citing Habermas' Erkenntnis und Interesse [1968]), the grounded theory (at least as far as the 'open', axial, and discriminate coding techniques are concerned) and thematic analysis.

\section{Narratological concerns}

Finding a written life of Caesar Augustus in Propertius is also a narratological problem. The poems are set in a more or less made-up story-world and told by made-up speakers with agendas that are not always clear. The text presents us with a poetic persona, which, in turn, presents us with a specific narrator for each of the poems, who may or may not be the same, but more importantly, may be equally untrustworthy or biased as a historical source. The text also depicts various characters - some of which are invented and not real (Cynthia), some of which are invented and real (Jupiter), and some of which are not invented and also real (Caesar Augustus). As the article will be borrowing from narratology, this seems like a good place to disclose the general assumptions upon which this borrowing will take place.

Pertinent to this analysis is the narratological concepts of 'character' and 'characterisation'. In narratology the term 'character' is 'used to refer to participants in story-worlds created by various media in contrast to "persons" as individuals in the real world'. ${ }^{2}$ (The audience do generally not participate in the story-world in narratology.) 'Characterisation' can be defined as '... the process of ascribing properties to names which results in agents having these properties in the story-world' (Jannidis 2013:§3). Traditionally, characterisation has been described as direct or indirect: direct characterisation occurs when a trait is ascribed explicitly to a character and indirect characterisation, 'when it is the result of inferences drawn from the text based partly on world knowledge' - the so-called cultural encyclopaedia (Jannidis 2013:§2-3). The latter applies specifically to the case of Caesar Augustus in Propertius where the process of characterisation is driven by both the text and by the cultural

1.Drisko and Maschi (2016:3-5) succinctly discusses the various problems with the definition of latent content in content analysis and its function in the practise of content analysis.

2.These definitions are indebted to the living handbook of narratology [sic]. This excellent resource is edited by Peter Hühn et al. (2008-2019) under De Gruyter. This particular entry is by Jannidis (2013), paragraph 2. 
knowledge of its audience, who knows about the 'real' Caesar Augustus from other narratives.

Characterisation is also approached from the viewpoint of the reader or audience. Where does the information come from by which a reader is able to come to know a character in the story-world? Margolin (1983) describes three sources for such information: explicit description in the text, inferences drawn from textual clues and inferences based on information which is not associated with the character by the text itself but through reference to historically and culturally variable real-world conventions' (Jannidis 2013:§22). These inferences can be understood as abductions in the Pierceian sense, that is, the character in the story-world is constructed by the reader according to character models from a character encyclopaedia in the cultural memory. Put differently, observers compare the character, which the narrative presents, with the character types with which they were programmed and use the archetypes to fill in details about the character inevitably not given by the narrative. It is in this last process that the problem with characterising Caesar Augustus is most keenly felt.

The characterisation of Caesar Augustus in Propertius is problematised by these inferences made by an audience that has prior knowledge of the character, as he is written in other texts. We refer to some of these texts as history, but the distinction was not that clear-cut in antiquity. If we want to ask how historical the Propertian text is, we first need to ask to what extent this Propertian construction of Augustus matches the audience's idea of the historical Augustus, or from a literary perspective, to what extent the life of Augustus in the Propertian text is limited by the life of Augustus outside of the text.

\section{Content analysis}

The content analysis is presented in tabular format with the designation on the left followed by the book, poem and verse number (following Heyworth 2007a), and finally the immediate context intended to serve as a reminder rather that an analytical tool (see Table 1).

According to this count, the Propertian corpus refers to Caesar Augustus at 40 places. Each mention is counted separately, and lines where the name appears twice, are counted twice $(2.7 .5,2.16 .41$ and 4.6.39). Second person pronouns referring to Caesar Augustus, mostly from Apollo's speech in 4.6.37-54, as well as the implied subject to the second person singular verb in 4.6.43, were also included as individual mentions. Each oblique mention or reference to Augustus was also counted. Summarised the designations for Caesar Augustus are: Caesar (20 times), Augustus (7 times), second person pronouns (9 times), oblique references (4 times).

The exact number of references to Caesar Augustus is not particularly important for the analysis, but they do demonstrate that he is named an inordinate number of times in Propertius - considerably more than in Horace, Vergil or
TABLE 1: Incidence of the character Augustus Caesar in Propertius.

\begin{tabular}{|c|c|c|}
\hline Designation & Locus & Immediate context \\
\hline Caesar & 1.21 .7 & Gallum per medios ereptum Caesaris enses \\
\hline Caesar & 2.1 .25 & bellaque resque tui memorarem Caesaris, et tu \\
\hline Caesar & 2.1 .26 & Caesare sub magno cura secunda fores \\
\hline Caesar & 2.1 .42 & Caesaris in Phrygios condere nomen avos \\
\hline Caesar & 2.7 .5 & 'At magnus Caesar'. sed magnus Caesar in armis: \\
\hline Caesar & 2.7 .5 & 'At magnus Caesar'. sed magnus Caesar in armis: \\
\hline dux meus & 2.10 .4 & et Romana mei dicere castra ducis \\
\hline Augustus & 2.10 .15 & India quin, Auguste, tuo dat colla triumpho, \\
\hline te & 2.10 .16 & et domus intactae te tremit Arabiae \\
\hline tuus & 2.10 .19 & haec ego castra sequar; vates tua castra canendo \\
\hline Caesar & 2.16 .41 & Caesaris haec virtus et gloria Caesaris haec est: \\
\hline Caesar & 2.16 .41 & Caesaris haec virtus et gloria Caesaris haec est: \\
\hline Caesar & 2.31 .2 & porticus a magno Caesare aperta fuit \\
\hline Caesar & 2.34 .62 & Caesaris et fortis dicere posse ratis, \\
\hline Caesar & 3.4 .1 & Arma deus Caesar dites meditatur ad Indos, \\
\hline Caesar & 3.4 .13 & qua videam spoliis oneratos Caesaris axes, \\
\hline proles Veneris & 3.4 .19 & ipsa tuam serva prolem, Venus: hoc sit in aevum, \\
\hline Caesar & 3.9 .27 & et tibi ad effectum vires det Caesar, et omni \\
\hline Augustus & 3.11 .50 & et longum Augusto salva precare diem! \\
\hline cives & 3.11 .55 & Non hoc, Roma, fui tanto tibi cive verenda!' \\
\hline Caesar & 3.11 .66 & vix timeat salvo Caesare Roma lovem \\
\hline Caesar & 3.11 .72 & Caesaris in toto sis memor lonio \\
\hline Augustus & 3.12 .2 & miles et Augusti fortia signa sequi? \\
\hline Caesar & 4.1 .46 & uexit et ipsa sui Caesaris arma Venus, \\
\hline Caesar & 4.6 .13 & Caesaris in nomen ducuntur carmina: Caesar \\
\hline Caesar & 4.6.14 & dum canitur, quaeso, luppiter ipse uaces! \\
\hline Augustus & 4.6 .23 & hinc Augusta ratis plenis louis omine uelis, \\
\hline Augustus & 4.6 .29 & astitit Augusti puppim super, et noua flamma \\
\hline servator & 4.6 .37 & mox ait 'o Longa mundi seruator ab Alba, \\
\hline Augustus & 4.6 .38 & Auguste, Hectoreis cognite maior auis, \\
\hline te & 4.6 .39 & uince mari: iam terra tua est: tibi militat arcus \\
\hline tuus & 4.6 .39 & uince mari: iam terra tua est: tibi militat arcus \\
\hline te & 4.6 .41 & solue metu patriam, quae nunc te uindice freta \\
\hline te & 4.6 .42 & imposuit prorae publica uota tuae \\
\hline te & 4.6 .43 & quam nisi defendes, murorum Romulus augur \\
\hline te & 4.6 .46 & principe te fluctus regia uela pati \\
\hline te & 4.6 .47 & nec te, quod classis centenis remiget alis, \\
\hline Caesar & 4.6 .56 & proxima post arcus Caesaris hasta fuit \\
\hline Augustus & 4.6 .81 & siue aliquid pharetris Augustus parcet Eois, \\
\hline Caesar & 4.11 .58 & defensa et gemitu Caesaris ossa mea \\
\hline
\end{tabular}

the other elegists. This is a surprising amount, considering that we are reading elegiac poetry. Many instances refer to Caesar Augustus merely in his capacity as imperator (i.e. the possessor of military power) or in terms of the gens Iulia without expressly making value judgements of his person or office, or having him play a part as a character in the storyworld. Yet, a few instances do contain extended descriptions of the man, his past and his current state.

Most of the references occur in the second and third Propertian books (as we call them today). The notable exceptions are the final two poems of the first collection and the central poem 4.6 in the last. The final two poems of the first collection function as a kind of sphragis to that volume, in which the speaker volunteers some biographical information, and in poem 4.6 the battle of Actium is narrated in a very peculiar manner. The simple explanation for this distribution, is that the first book was written before Propertius came into and under the protection of the Maecenaean circle, and the 
last was written (c. $16 \mathrm{BCE})^{3}$ after the pressure of the so-called Augustan programme wore off and many of the issues of the twenties had disappeared. The fourth book is also generically slightly different from the others. It is composed exclusively of longer poems of a slightly different nature and contains several aetiological poems.

In the next section, the discussion of the content analysis will proceed generally in a diachronic fashion. The narratological assumption is that the characterisation of Caesar develops as the story-world develops, and the text reveals its characters gradually. The content analysis bears this out. As the discussion will show, Caesar first appears as a rather vague background character used to paint a political context for different poems. Caesar soon becomes a more important character in the mind of the narrator and Caesar's imagined requirements, and requests begin to occupy the thoughts of the narrator.

\section{The second book}

The content analysis reveals that magnus is the most common adjective applied to Caesar Augustus. Magnus is a deliciously generic term for denoting largeness, greatness, prominence, importance and power. By far the greatest majority of references to Augustus in Propertius depict him as the possessor of weapons or instruments of war and, consequently, of military power. In fact, the data suggests that this is the distinguishing attribute of the Propertian Augustus. Representative examples include: in 1.21.7, Gallus escaping per medios ... Caesaris enses; in 2.34.62, Virgil is allowed to sing about the Caesaris ... fortis ... ratis; in 3.4.1, Arma deus Caesar dites meditatur ad Indos; in 3.12.2, Postumus is following the Augusti fortia signa, and in 4.1.46, Venus herself uexit ... sui Caesaris arma. Closely associated with the instruments of war are the produce thereof: the spolia (3.4.13), the wealth (3.4.1-2), the power $(2.1 .26,3.9 .27)$, the gloria $(2.16 .41,3.11 .50,4.6 .13)$. So many are the references to Caesar's triumphs and deeds that, at least at one point in book 2, they are merely abbreviated (Propertius 2.1.25-26):

bellaque resque tui memorarem Caesaris, et tu

Caesare sub magno cura secunda fores.

[I will commemorate the wars and deeds of your <sc. Maecenas'> Caesar, and you, second to great Caesar, will be my concern. (author's own translation)]

The Propertian text seems keenly aware that it is typecasting its character of Augustus as a warlord and comparatively early we have an overt delimitation of his power. Propertius 2.7.1-6 is worth a closer look (translated from Heyworth 2007b:538):

Gavisa es certe sublatam Cynthia legem, qua quondam edicta flemus uterque diu,

ni nos divideret: quamvis diducere amantis non queat invitos Iuppiter ipse duos.

3.Propertius' first book probably appeared no later than 28 BCE, if not in that year (Manuwald 2006:224-225), but see also Heslin (2010:54-59) who argues for a date before the Battle of Actium. The books that now comprise our books 2 and 3 , appeared after 24 BCE (Camps 1966:1; Richardson 1977:7-9), probably 23 or early 22 BCE (Richardson 1977:10). Book 4 is no earlier than 16 BCE (Hutchinson 2006:2 3 and especially O'Rourke 2010:470-471 n.5), which contains a virtual annotated bibliography on the dating of Propertius 4.

\section{'At magnus Caesar'. sed magnus Caesar in armis: devictae gentes nil in amore valent.}

[Cynthia you surely rejoiced at the repealing of the law, ${ }^{4}$ at the promulgation of which we cried for long, lest it would separate us: although Jupiter himself, cannot divide two lovers against their will. 'But Caesar is great ...' but great in war: conquered people count for nothing in love. $]^{5}$

This particular delimitation of Caesar Augustus' greatness becomes topical in the opening of the third book. For now Caesar appears in the background of the Propertian storyworld as part of the political landscape. This recusatio that opens book 2 is, after all, addressed to Maecenas, referencing Caesar obliquely and this poem (2.7) features only Cynthia and the speaker as characters.

The next cluster of mentions of Caesar Augustus appears in poem 2.10. This poem is a recusatio like poem 2.1 and Caesar's name features in the section where possible topics are mentioned about which the speaker would have sung if he had that kind of talent. The Caesar of this poem is still the warlord of poems 2.1 and 2.7 and the association between Caesar and wealth, gained through conquest or on the point of being gained, is again pronounced. This poem also introduces three new features of the Propertian Caesar: (1) Caesar is called Augustus (this is the first instance in Propertius), (2) Caesar is described as the leader of a camp, that is, an imperator during a campaign ${ }^{6}$ and (3) Caesar, or his camp at least, has the means or capacity to make the poet great (Propertius 2.10.13-20):

iam negat Euphrates equitem post terga tueri Parthorum et Crassos se tenuisse dolet:

India quin, Auguste, tuo dat colla triumpho, et domus intactae te tremit Arabiae;

et si qua extremis tellus se subtrahit oris, sentiat illa tuas postmodo capta manus!

haec ego castra sequar; vates tua castra canendo magnus ero: servent hunc mihi fata diem!

[Now the Euphrates denies the Parthian cavalry cover from behind and is sorry that he held the Crassi back: Even India, Augustus, give its neck for your victory, and the house of united Arabia trembles before you; and if any land hides itself in the furthest corner, let it be occupied and feel your hand afterward. I follow these camps, I'll be a great poetpriest to sing of your camp: May the fates protect this day for me. (author's own translation)]

The use of the name Augustus is curious, but it is not clear if it is entirely meaningful in the Propertian context. Vergil, the
4.The law in the first line is apparently not the Lex Iulia. Miller (2002:187-188) quotes Badian (1985:82-98) who shows that none of the laws that 'brought back the many examples of the ancestors ... to be imitated by posterity' about which Augustus brags in the Res Gestae 8.5 were in fact passed at this time. Badian's solution is that the laws that so vexed the poet and Cynthia were, in fact, laws levying tax on unmarried men. However, the exact nature of the poet's relationship with his puella is not our concern here. More interesting is the limitations placed on Caesar's power.
5.Richardson (1977:231) notes that the meaning of line 6 must be 'deuicisse gentes nil in amore valet' following Butler and Barber (1933:203). Goold (1990:139) has 'in love the defeat of nations count for naught'.
6.A distinction ought to be made between the praenomen Imperator and the title. Julius Caesar (according to Dio 43.44.2-3 and Suet. Caes. 76.1) received the title for life with the right to pass it on to his descendants. The young Octavian assumed the life with the right to pass it on to his descendants. The young Octavian assumed the evidence (see Kearsley 2009:154). 
supreme craftsman and the poet closest to Caesar, reserved his two uses of the name Augustus for Aeneid 6.792 in the parade of heroes and Aeneid 8.678 in the Shield of Aeneas. These two instances are clearly and significantly cosmological. ${ }^{7}$ Propertius' use here is not overtly cosmological, but he would use the name Augustus again in 3.11, 3.12 and 4.6, the former and latter of which is in a cosmological context.

The casting of Caesar, as the imperator of a military camp, is developed in the third book. The position of Caesar as imperator and his relationship to the speaker is significant. In 2.10 the speaker reveals that he would follow the Caesarean camp and that he will sing about these camps (2.10.19). But not only this. In singing about these camps, the speaker feels he will become magnus (2.10.20). The use of the same adjective applied to Caesar is pointed: the relationship between Caesar and the speaker has the potential to make the poet powerful like Caesar. This ability of Caesar to make the speaker great or famous is also developed further in the third book.

\section{The third book}

The opening of 3.4 is more than a little shocking: arma deus Caesar dites meditatur ad Indos [the god Caesar is planning war against rich India]. It is not that Caesar Augustus is contemplating going to war, but that he is called deus.

Augustus was, of course, styled filius dei soon after 44 BCE (Pliny HN 2.93-94 and Ovid Met. 15.760-761), and he soon appeared as a saviour figure (Vergil E. 1). In the provinces, Caesar Augustus was honoured among local deities (Appian $B C$ 5.546), and in the Res Gestae $25.2^{8}$ we read that oaths were sworn in his name. In Rome herself, however, Caesar Augustus never presented himself as a deity, and it seemed the furthest one could go in poetry is Horace C. 3.5.1-4 (dated to $27 \mathrm{BCE}$ or immediately after Caesar adopted the name Augustus) (Galinsky 1996:259-260).

The idea that Caesar Augustus is the imperator of a camp or faction (2.10.4) is also developed in 3.4 and 3.5. The two poems neatly divide the world into two camps: those who follow deus Caesar and the amantes (lovers) who follow pacis Amor deus. The speaker is in the latter group, of course. In Augustan poetry the poet-lover rejects acquisitiveness and the quest for military glory. In the two poems, both ways of life are described at length and each is associated with other things: the life of war is not only war, but also riches and glory, while the life of poetry is also one of love-making and drinking. On the side of those who choose a life of war and the pursuit of wealth, Propertius places Caesar Augustus (3.4.1), Latin Jupiter (3.4.6) and Mars (3.4.11). On the side of those who choose peace, he puts himself (3.5.1) and the Muses (3.5.20). Associated with the former are journeys over the ocean to the ends of the Empire (3.4.1-6) - in 3.4 India is named as well as the Tigris and the Euphrates.

\footnotetext{
7.Hardie (1986:66-68, 353-356) famously discusses the cosmological dimension of E.9.47, G.1.25, 1.466, 1.503, 2.170, 3.16, 3.47, 3.48, 4.560 A.1.286, 6.789, 6.792, $8.678,8.714$. These too, are often in cosmological contexts.
}

8.For a discussion of the Res Gestae 25.2, see Habinek (1998:91)
The two poems also contrast the motives of the poet and the general. Although Caesar Augustus is placed among the warmongers, Propertius is careful not to dismiss his motives as has been done in the case of Crassus whose disastrous expedition of 53 BCE was believed to be motivated by avarice. ${ }^{9}$ According to the poet of 3.4, greed and warmongering are not the motivation behind Caesar Augustus' eastern campaigns. Lines 4-6 explain that the eastern lands must be subdued and controlled - the rivers (4), the province (5) and their trophies (6) - and that this should be done 'to pay the ghosts of the Crassi ${ }^{10}$ their due and purge our defeat' as Camps (1966:71) puts it. The passage under discussion (3.4.9-10) reads:

omina fausta cano. Crassos clademque piate! ite et Romanae consulite historiae!

[I foretell favourable omens. Expiate the massacre of the Crassi! Go! And reflect upon the history of Rome! (author's own translation) $]^{11}$

The verb piare has strong religious overtones and saying that the disaster suffered by Crassus must be expiated or atoned for, makes it almost a religious mandate. The idea that Caesar Augustus has some kind of divine purpose to save Rome or correct Roman history is known from Vergil's Eclogues, but appears here for the first time in Propertius. ${ }^{12}$ It is also here that the simple binary division, suggested by the opening lines of 3.4 and 3.5, breaks down: while Caesar Augustus does what the rich warmongers do, he is excused after a fashion, as his motives are honourable insofar that he aims to serve Rome. This particular aspect of Augustus will feature again in 3.11.50, 3.11.72, and in the speeches of Apollo and Julius Caesar in 4.6.

After extolling the glories gained by Caesar in 3.4.1-20, but before stating that poets venerate peace in the next poem, the speaker inserts an important self-revelation (Propertius 3.4.21-22):

$$
\begin{aligned}
& \text { praeda sit haec illis, quorum meruere labores: } \\
& \text { me sat erit Sacra plaudere posse Via. }
\end{aligned}
$$

[Let these spoils go to them who earned it with their toils; for me it shall be enough to be able to applaud them on the Via Sacra. (author's own translation)]

The poet is careful here to mention that he keeps himself far away from the actions of state. He will do so again later in the third book and, in general, will keep the promises

9.Ancient historical narratives on the battle of Carrhae - Dio Cassius and Plutarch's Crassus - paint Crassus' downfall as an example of nemesis following on hubris (Marshall 1975:147). For a discussion of the battle of Carrhae and insightful observations about how the Romans remembered their military defeats, see Mattern-Parkes (2003:387-396)

10.The plural is not poetic: both Marcus Licinius Crassus and his son died at this battle.

11.Goold (1990:265) translates this passage with: 'Fair are the omens of my song. Make expiation to the Crassi and their defeat! Away, and serve Rome's history well!' The verb consulere covers a wide semantic domain and its meaning(s) in this particular passage is open for interpretation. Yet, as far as the argument presented charged with Roman history.

12.The idea of a divine saviour is not from the famous Messianic eclogue, but from the first poem in the collection (probably composed last.) For an in-depth discussion of the relationship between Vergil's Eclogues and the patronage of what was then Octavian, see Weeda (2015:70-71) and especially the bibliography in note 89 
not to contribute to current affairs through poetry. This is significant, as earlier (2.10), the speaker expressed the belief that following the camp of Caesar would make him great. This assertion here of his unwillingness to do so, suggests (but does not overtly say) that the speaker does not belong to the Caesarean camp as it exists in the storyworld of the poems.

Caesar Augustus is mentioned again in 3.11. This poem celebrates the battle of Actium like poem 4.6 does (to which we will turn later), but unlike poem 4.6 , this poem dwells on the emotional reaction to the outcome of the battle. The poem is acerbically critical of Cleopatra ${ }^{13}$ and adulates Augustus unapologetically. Yet, as in 3.4, the speaker 'is careful to make his own engagement with his subject only that of a spectator' (Richardson 1977:359). The idea that Caesar Augustus is a saviour and corrector of Roman history is very pronounced, but also strangely undercut (Propertius 3.11.47-50):

$$
\begin{aligned}
& \text { quid nunc Tarquinii fractas iuvat esse secures, } \\
& \text { nomine quem simili vita superba notat, } \\
& \text { si mulier patienda fuit? cane, Roma, triumphum } \\
& \text { et longum Augusto salva precare diem! }
\end{aligned}
$$

[What does it help now that the fasces of Tarquin were broken, he whose proud life gave him a similar name, if we were to suffer a woman? < i.e., to rule us 11. 45-46 above > Sing out, Rome, the triumph, and saved $<$ city> pray long life for Augustus. (author's own translation)]

Then we are also given testimony from an inebriated Cleopatra (Propertius 3.11.55-56):

\section{'Non hoc, Roma, fui tanto tibi cive verenda!' dixit et assiduo lingua sepulta mero.}

['I was not to be feared when you had such a citizen, Rome', the tongue buried in constant wine had said. (author's own translation) $]^{14}$

To be sure, the assessment volunteered by a habitually drunk eastern woman ${ }^{15}$ somehow rings a false note in the otherwise straightforward panegyric ${ }^{16}$ and it is not clear why Cleopatra, whom most of the preceding verses vilified, would be used to deliver such a remark. Because the text is severely corrupt at this point, ${ }^{17}$ it is problematic to make too much of this. Moreover, a content analysis emphasises the general over the particular and in this case it seems sufficient to note the messianic facet attributed to Caesar again.

13.The abuse hurled at Cleopatra here in 3.11.33-58, is not unfamiliar and examples can be found in Aeneid 8. 685-688, 696-713, Epode 9, and Odes 1.37.

14. Heyworth (2007b:341) does not believe these words are meant to be spoken by Cleopatra and does not print the quotation marks in his text. In the same paragraph he does, however, concede that it is 'more probably Propertian [to select] the version that has even the wine sodden tongue of Cleopatra acknowledging the power of Augustus'. Nevertheless, Heyworth (2007b:575) prints the quotation marks in the translation: "I was not to be feared when you had such a citizen, Rome", the tongue buried in constant wine had said'.

15.In Horace (C. 1.37.14), Cleopatra also appears as someone who drinks too much.

16.This may not be a typical panegyric in a programmatic sense, but the content is definitely pro-Augustus. For a discussion of the programmatics of this poem, see Newman (1997:255-262).

17.See especially Richardson (1977:366), but also Heyworth (2007b:341).

\section{The fourth book}

The various different strands of Caesar Augustus' character are drawn together in the centrepiece of Propertius' last book: 4.6. The content analysis reveals that this poem contains the highest frequency of mentions of Caesar Augustus and, if one goes by a simple count alone, this poem constitutes just more than a third of all the mentions. The simple count is of debatable significance, but what is significant is that, in this poem, Caesar Augustus plays an active role in the events described by the poem - most notably in the sense that he is directly addressed by Apollo. He is not, as earlier, a character that is part of the background or political context.

Propertius 4 was written at least six years after book 3 , the poems are markedly different in style ${ }^{18}$ and generally much longer. The collection contains several aetiological poems and 4.6 is one of them. This, the central poem in the 11 poem collection, purports to be about the temple of Apollo on the Palatine and tells of the battle of Actium. Poem 4.6 has been variously deplored and lauded. The nationalist theme and the seemingly overenthusiastic panegyric was not popular during the 1960s and 1970s. ${ }^{19}$ In short, the problem was believed to concern the Augustanism or anti-Augustanism of the text. ${ }^{20}$ That is, the poet of 4.6 is either: (1) a poet from Maecenas' circle that succumbed to external pressure from the leading men in Rome and is singing the praises of the new princeps (a position that modern critics find difficult to admire); or (2) he is still a dissident who deplored the civil war (see poems 1.21 and 1.22), ostensibly cast himself as a pacifist (poems 3.4 and 3.5) and repeatedly refused to write poetry about war or politicians (poems 2.1, 2.10 and 3.3 among other). Now, in 4.6 , the poetic persona is not yet ready to surrender his recalcitrant views; he is only more careful and is prepared to hide them.

Whatever the ideological position of the speaker of 4.6 may be, the poem itself admits that it is about the temple of Apollo on the Palatine and that it is sung 'in the name of Caesar' and in the presence of Jupiter (Propertius 4.6.11-14):

Musa, Palatini referemus Apollinis aedem: res est, Calliope, digna favore tuo.

Caesaris in nomen ducuntur carmina: Caesar dum canitur, quaeso, Iuppiter ipse vaces!

18.An excellent discussion on this topic can be found in Hutchinson $(2006: 1-2,7-15)$.

19.'One of the most ridiculous poems in the Latin language' (Williams 1962:43) and a 'deliberately and unavoidably poor poem on Actium' (Sullivan 1972:30). The latter view was repeated throughout the 1970s (Commager 1974:64 n.62; Galinsky 1969:86; Sullivan 1976:71 n.8). The lone dissident was Johnson (1973:151-180) who criticised the named authors for their 'failure to appreciate the poetic merits of the piece', and today critics are more neutral about the artistic merits of the piece as Hutchinson (2006:154) claims: '[A poem veering] between imposing laudation and obsession with its own oddity and with genre'; or even positive as Günther (2006:379): 'this highly sophisticated poem may be regarded, together with $4.7,8$, and 11 , as a peak of Propertius' art'.

20.Cairns (2006:356) optimistically states that there should nowadays be 'little doubt about the genuinely Augustan character of Book 4', citing his own 'Augustan' interpretation of the poem (1984:129-164) and that 'there are no grounds for thinking that Propertius subscribed to [an Augustan programme] involuntarily'. thinking that Propertius subscribed to [an Augustan programme] involuntarily'.
But see also Kennedy (1997:26-58) on the problems of modern labels for But see also Kennedy (1997:26-58) on
(perceived) ideologies in Augustan Rome. 
[Muse, we shall speak of the Temple of Palatine Apollo: it is a subject, Calliope, worthy of your favour. The songs are composed in the name of Caesar: while Caesar is being sung, Jupiter, I beg you, yourself, to listen. (author's own translation) $]^{21}$

The main panegyric focus of the poem falls on Apollo's speech (4.6.37-54; Coleman 2003:39-40) and it is here where practically all the mentions of Caesar Augustus are concentrated. These mentions are mostly through second person pronouns and, if frequency of incidents is considered significant for the content analysis, this cluster of incidents would present an interpretative problem. Yet, whether this cluster is considered one incident or nine (as the count in the table above), is not the most important point. The amount of description concerning Caesar Augustus here is considerably more than at any other mention of the character.

The speech of Apollo, as far as the characterisation of Caesar Augustus is concerned, says little more than what has already been said in earlier poems. The only, but significant difference is that it is now being said by a deity. ${ }^{22}$ Now, the attributes, assigned to Caesar in the Propertian story-world, are legitimatised (after a fashion) by Apollo, which does not only make the written Caesar Augustus more 'real', but also legitimises the narrator who assigned these attributes to him in the first place. Apollo immediately addresses Caesar Augustus as servator (4.6.37), then with the vocative Auguste (4.6.38). He expresses fidelity to Augustus and his cause (4.6.39-40), and emphasises the importance of Augustus' mission to correct the history of Rome (4.6.41-44). These are all things already attributed to Augustus in the earlier books. The only difference is that here everything is crammed into one divine speech. Yet, despite his dramatic entrance into the scene accompanied by lightening, Apollo's speech 'seems to say all the right words, but somehow the overall effect of his words is not quite right' (Gurval 1995:266). Neither in his speech, nor in the rest of the poem does Caesar Augustus emerge as a victor.

\section{Conclusion}

The Caesar Augustus, as he is developed as a character in the Propertian story-world, is mainly a somewhat distant ruler. $\mathrm{He}$ is magnus and the possessor of great power, especially military power, wealth and influence. To be sure, during the twenties, no one (maybe not even the man himself), knew exactly what type of ruler he would be. Propertius, who was not as close to him as say Horace or Vergil, seems to be struggling to describe the new power structures in the new dispensation. In this, the Propertian text is probably representative of the general apprehension among the Roman elite.

The casting of Augustus as saviour of the Roman people and corrector of history is a recurring theme, but seems to

21. Hutchinson (2006:157), strangely takes luppiter ipse vaces to mean that Jupite should 'go without being sung' and cites Propertius 1.13.2 in support ... quod abrepto solus amore vacem [.. because with love torn away, I am alone and empty]. Vaces is solus amore vacem [... because with love torn away, I am alone and empty]. Vaces is best taken as 'may you be unoccupied' or 'may you be free to attend' as it is understood by Butler and Barber (1933:356), Camps (1965:106) and Richardson 1977:448) and is used in almost the same way in Propertius 4.11.23 Sisyphe, mole vaces [Sisyphus, take a break from the weight (of the rock you are pushing)]

22.The technique of using a divine spokesperson to extol the virtues of the recipient of the praise is typically Hellenistic (Coleman 2003:37). be based on literary inventions. The messianic role Augustus is given in Vergil's Eclogues is probably just an example of many messianic hopes put in verse (maybe hope was placed in different individuals). It is not difficult, at any rate, to see how this messianic poetry coupled with the hope, kindled by the few years of peace after Actium led to the new chief executive in the senate being cast as the 'chosen one', that would restore the greatness of the city. This is not, however, to say that Caesar orchestrated a propaganda programme or arranged a systematic marketing strategy regarding his public image through the poetry of Propertius.

The character of Caesar Augustus in Propertius seems poorly formed - especially compared to a deliciously full character like Cynthia. Even in poem 4.6 where Caesar plays a much larger role than in any other poem, his character is revealed more by the action of other characters such as Julius Caesar and Apollo, than by actions he takes himself. The incompleteness of Caesar Augustus' character is not entirely unexpected: the historical Augustus, as far as he is portrayed in the Augustan textual accounts, is difficult to know. Partly because he was naturally a private individual, but definitely also because maintaining personal privacy was for a man in his position the sensible thing to do. One would assume that nobody knew all the aspects of the man (and if Maecenas or Agrippa did, we do not have their biographies); most people, the contemporary poets included, knew Augustus the same way we do - secondhand through the story-worlds of others' texts.

\section{Acknowledgements Competing interests}

I declare that I have no financial or personal relationships which may have inappropriately influenced me in writing this article.

\section{Author's contributions}

I declare that I am the sole author of this research article.

\section{Ethical consideration}

This article followed all ethical standards for a research without direct contact with human or animal subjects.

\section{Funding information}

This research received no specific grant from any funding agency in the public, commercial, or not-for-profit sectors.

\section{Data availability statement}

Data sharing is not applicable to this article as no new data were created or analysed in this study.

\section{Disclaimer}

The views and opinions expressed in this article are those of the authors and do not necessarily reflect the official policy or position of any affiliated agency of the authors. 


\section{References}

Badian, E., 1985, 'A phantom marriage law', Philologus 129, 82-98. https://doi. org/10.1524/phil.1985.129.12.82

Berelson, B., 1952, Content analysis in communication research, The Free Press, Glencoe. Butler, H.E. \& Barber, E.A., 1933, The elegies of Propertius, Clarendon Press, Oxford.

Cairns, F., 1984, 'Propertius and the battle of Actium (4.6)', in T. Woodman \& D. West (eds.), Poetry and politics in the age of Augustus, pp. 129-168, Cambridge University Press, Cambridge.

Cairns, F., 2006, Sextus Propertius: The Augustan elegist, Cambridge University Press, Cambridge.

Camps, W.A., 1965, Propertius: Elegies book IV, Cambridge University Press, Cambridge. Camps, W.A., 1966, Propertius: Elegies book III, Cambridge University Press, Cambridge.

Coleman, K., 2003, 'Apollo's speech before the battle of Actium: Propertius 4.6.37-54', in A.F. Basson \& W.J. Dominik (eds.), Literature, art, history: Studies on classical antiquity and tradition: In Honour of W.J. Henderson, pp. 37-45, Peter Lang, Frankfurt.

Commager, S., 1974, A prolegomenon to Propertius, University of Oklahoma Press, Norman, OK.

Drisko, J.W. \& Maschi, T., 2016, Content analysis, Oxford University Press, Oxford.

Galinsky, K., 1969, 'The Triumph theme in Augustan elegy', Wiener Studien 82, 75-107.

Galinsky, K., 1996, Augustan culture, Princeton University Press, Princeton, NJ.

Goold, G.P., 1990, Elegies: Propertius, Harvard University Press, Cambridge, MA.

Günther, H.-C., 2006, 'The fourth book', in H.-C. Günther (ed.), Brill's companion to Propertius, pp. 353-398, Brill, Leiden.

Gurval, R.A., 1995, Actium and Augustus: The politics and emotions of civil war, University of Michigan Press, Ann Arbor, Ml.

Habermas, J., 1968, Erkenntnis und Interesse, Suhrkamp Verlag, Frankfurt am Main,

Habinek, T.N., 1998, The politics of Latin literature: Writing, identity, and empire in ancient Rome, Princeton University Press, Princeton, NJ.

Hardie, P., 1986, Vergil's Aeneid: Cosmos and imperium, Clarendon Press, Oxford.

Heslin, P., 2010, 'Virgil's Georgics and the dating of Propertius' first book', Journal of Roman Studies 100, 54-68. https://doi.org/10.1017/S0075435810000055

Heyworth, S.J., 2007a, Sexti Properti Elegos, Clarendon Press, Oxford.

Heyworth, S.J., 2007b, Cynthia: A companion to the text of Propertius, Oxford University Press, Oxford.

Hühn, P., Pier, J., Schmid, W. \& Schönert, J. (eds.), 2008-2019, The living handbook of narratology, De Guyter, Hamburg, viewed 27 September 2016, from http://www. Ihn.uni-hamburg
Hutchinson, G., 2006, Propertius: Elegies book IV, Cambridge University Press, Cambridge.

Jannidis, F., 2013, 'Character', in P. Hühn, J. Pier, W. Schmid \& J. Schönert (eds.), The living handbook of narratology, De Guyter, Berlin, viewed 27 September 2016 from http://www.lhn.uni-hamburg.de/article/character

Johnson, W.R., 1973, 'The emotions of patriotism: Propertius 4.6', California Studies in Classical Antiquity 6, 151-180. https://doi.org/10.2307/25010652

Kearsley, R., 2009, 'Octavian and augury: The years 30-27 B.C.', The Classical Quarterly 59(1), 147-166. https://doi.org/10.1017/S0009838809000123

Kennedy, D., 1997, “"Augustan" and "anti-Augustan": Reflections on terms of reference', in A. Powell (ed.), Roman poetry and propaganda in the age of Augustus, pp. 26-58, Classical Press, Bristol.

Levene, D.S. \& Nelis, D., 2002, Clio and the poets: Augustan poetry and the traditions of ancient historiography, Brill, Leiden.

Manuwald, G., 2006, 'The first book', in H.-C. Günther (ed.), Brill's companion to Propertius, pp. 219-244, Brill, Leiden.

Margolin, U., 1983, 'Characterisation in narrative: Some theoretical prolegomena', Neophilologus 67, 1-14. https://doi.org/10.1007/BF01956983

Marshall, B.A., 1975, Crassus: A political biography, Adolf M. Hakkert, Amsterdam.

Mattern-Parker, S.P., 2003, 'The defeat of Crassus and the Just War', Classical World 96, 387-396. https://doi.org/10.2307/4352789

Mayring, P., 2000, 'Qualitative content analysis', Forum Qualitative Sozialforschung / Forum: Qualitative Social Research 1(2), viewed 05 June 2019, from http://www. qualitative-research.net/index.php/fqs/article/view/1089/2383

Miller, P.A., 2002, Latin erotic elegy: An anthology and reader, Routledge, London.

Newman, J.K., 1997, Augustan Propertius: The recapitulation of a genre, G. Olms, Hildesheim.

O'Rourke, D., 2010, 'Maxima Roma in Propertius, Virgil, and Gallus', Classical Quarterly 60(2), 470-485. https://doi.org/10.1017/S0009838810000170

Richardson, L., 1977, Propertius: Elegies, I-IV, University of Oklahoma Press, Norman, OK.

Sullivan, J.P., 1972, 'The politics of elegy', Arethusa 5(1), 17-34.

Sullivan, J.P., 1976, Propertius: A critical introduction, Cambridge University Press, Cambridge.

Syme, R., 1950 [1939], The Roman revolution, Oxford University Press, Oxford.

Weeda, L., 2015, Vergil's political commentary in the Eclogues, Georgics and Aeneid, De Gruyter, Berlin.

Williams, G.W., 1962, 'Poetry in the moral climate of Augustan Rome', Journal of Roman Studies 52, 28-46. https://doi.org/10.2307/297875 